\title{
Prevalence of pathogens from Mollicutes class in cattle affected by respiratory diseases and molecular characteristics of Mycoplasma bovis field strains
}

\author{
Ewelina Szacawa ${ }^{1}$, Monika Szymańska-Czerwińska ${ }^{1}$, Krzysztof Niemczuk $^{1}$, \\ Katarzyna Dudek ${ }^{1}$, Grzegorz Woźniakowski ${ }^{2}$, Dariusz Bednarek ${ }^{1}$ \\ ${ }^{1}$ Department of Cattle and Sheep Diseases, \\ ${ }^{2}$ Department of Swine Diseases, \\ National Veterinary Research Institute, \\ 24-100 Pulawy, Poland \\ ewelina.szacawa@piwet.pulawy.pl
}

Received: October 3, $2016 \quad$ Accepted: November 23, 2016

\begin{abstract}
Introduction: Mycoplasma bovis is one of the main pathogens involved in cattle pneumonia. Other mycoplasmas have also been directly implicated in respiratory diseases in cattle. The prevalence of different Mycoplasma spp. in cattle affected by respiratory diseases and molecular characteristics of $M$. bovis field strains were evaluated. Material and Methods: In total, 713 nasal swabs from 73 cattle herds were tested. The $u v r C$ gene fragment was amplified by PCR and PCR products were sequenced. PCR/DGGE and RAPD were performed. Results: It was found that 39 (5.5\%) samples were positive for M. bovis in the PCR and six field strains had point nucleotide mutations. Additionally, the phylogenetic analysis of $20 \mathrm{M}$. bovis field strains tested with RAPD showed two distinct groups of $M$. bovis strains sharing only 3.8\% similarity. PCR/DGGE analysis demonstrated the presence of bacteria belonging to the Mollicutes class in $79.1 \%$ of DNA isolates. The isolates were identified as: Mycoplasma bovirhinis, M. dispar, M. bovis, M. canis, M. arginini, M. canadense, M. bovoculi, M. alkalescens, and Ureaplasma diversum. Conclusion: Different Mycoplasma spp. strains play a crucial role in inducing respiratory diseases in cattle.
\end{abstract}

Keywords: cattle, Mycoplasma, Ureaplasma, pneumonia, molecular characteristics.

\section{Introduction}

Mycoplasmas and Ureaplasma diversum belong to the Mollicutes class. It is well known that Mycoplasma bovis is one of the main pathogens involved in cattle pneumonia, especially in bovine respiratory disease complex (BRD). Usually the disease is associated with other pathogenic microorganisms such as viruses and other bacteria $(8,18)$. Other mycoplasmas including M. dispar, M. canis, M. arginini, and the related species $U$. diversum have been directly implicated in $\operatorname{BRD}(5,9,18)$. Moreover, other mycoplasma species such as $M$. alkalescens, $M$. canadense, and $M$. bovirhinis are involved in cattle respiratory infection $(13,18,25)$. M. bovis causes significant economic losses in the cattle industry, due to low growth rate of the animals and increased costs of treatment (21). Due to the difficulty of effective isolation of mycoplasmas under laboratory conditions, molecular methods are considered to be the most suitable and have recently been generally recommended for diagnosis of mycoplasmal infection (28). The survey of M. bovis spread and studies on its genetic diversity were performed in different parts of the world because $M$. bovis is well-equipped to generate diversity, and new clones may appear $(2,7$, 23, 29).

The aim of the study was to evaluate the prevalence of different Mycoplasma spp. and $U$. diversum in cattle affected by respiratory diseases and to study the molecular characteristics of field strains of $M$. bovis. In addition, this study allowed us to create the first report about the prevalence of diversity in the $u v r C$ gene, which so far has been considered to be a conservative one in the $M$. bovis genome. 


\section{Material and Methods}

Samples. The study was performed on 577 Black and White breed calves (ranging in age from two weeks to six months) and 136 Holstein-Friesian cows (ranging in age from two to five years) from 73 herds located in different regions of Poland (Table 1). In total, 713 nasal swabs were collected from the cattle following standard procedures by Veterinary Inspectorate officers and veterinary practitioners during clinical examination in 2014 and 2015. The samples were collected from herds in which the presence of respiratory diseases had been confirmed either by serological examination or the presence of clinical signs of infection. The swabs were collected into transport medium (Copan, USA) in duplicate: the first for DNA extraction and the second for bacterial culture.

Table 1. Number of herds and animals tested considering regions and provinces

\begin{tabular}{llll}
\hline Region & Province & $\begin{array}{l}\text { Number of } \\
\text { herds tested }\end{array}$ & $\begin{array}{l}\text { Number of } \\
\text { animals tested }\end{array}$ \\
\hline \multirow{2}{*}{ eastern } & Lublin & 6 & 119 \\
& Holy Cross & 1 & 11 \\
& Podlasie & 14 & 107 \\
& Podkarpacie & 1 & 6 \\
\hline central & Masovian & 14 & 128 \\
\hline northern & Pomeranian & 14 & 114 \\
\hline north- & Greater Poland & 11 & 99 \\
\hline western & Oputh- & 5 & 70 \\
western & Opole & 7 & 59 \\
\hline southern & Lesser Poland & 713 \\
\hline total & & 73 & 713 \\
\hline
\end{tabular}

Bacterial culture. M. bovis strains were isolated from the swabs. For this purpose, culturing in Eaton's agar (19) at $37^{\circ} \mathrm{C}$ and in $5 \% \mathrm{CO}_{2}$ for 5-7 $\mathrm{d}$ was performed and then culturing was continued in Eaton's broth for $48 \mathrm{~h}$.

DNA extraction. DNA extraction from swab samples was performed using the QIAmp DNA Mini Kit (QIAGEN, Germany) following the manufacturer's procedure. In cases where DNA was extracted directly from the swabs, negative results in PCR were obtained. Therefore, the DNA of each strain was extracted from $1 \mathrm{~mL}$ of broth culture according to Akwuobu et al. (1) and then the QIAmp DNA Mini Kit was applied.

PCR for $\boldsymbol{u v r C}$ gene. The specific primers were used (28). PCR was carried out in a T-personal thermocycler (Biometra, Germany) according to Subramaniam et al. (28) with modifications of the number of cycles, from 35 to 40 ; temperature of primer annealing, from $52^{\circ} \mathrm{C}$ to $60^{\circ} \mathrm{C}$; and elongation time, from $60 \mathrm{~s}$ to $90 \mathrm{~s}$. The DNA from nasopharyngeal swabs or, in cases when DNA concentration was too low, DNA from bacterial culture was used. The positive control (DNA obtained from the reference strain of $M$. bovis PG45: ATCC 25523) and water as negative control were used.
DNA sequencing and phylogenetic analysis. The PCR products were sequenced by Genomed (Poland). Each amplicon was analysed twice (forward and reverse) to ensure the reliability of the sequences. The sequences were compared with nine relevant sequences from GenBank and also with the closely related $M$. agalactiae strain. additionally, the predicted amino acid sequences were aligned. A dendrogram was plotted using a neighbour-joining $(\mathrm{NJ})$ algorithm with 1000-BOOTSTRAP replicate analysis by Mega 6.0 software (The Biodesign Institute, Arizona State University, USA). The sequences were plotted as a similarity matrix with the use of Geneious software $v$ 9.0.5 (Biomatters, New Zealand) based on percentage values.

Random amplification of polymorphic DNA (RAPD). The primers described by Hotzel et al. (10) were used. The PCR cycling conditions were reported by Byrne et al. (4). DNA from individual M. bovis isolates was used. Hybridisation profiles were analysed using BioNumerics software v 7.5 (Applied Maths, Sint-Martens-Latem, Belgium). Similarity between isolates was calculated using the Jaccard coefficient (11) and the dendrogram was constructed by the unweighted pair group method using arithmetic means (UPGMA) (27).

PCR/denaturing gradient gel electrophoresis (PCR/DGGE). PCR/DGGE was performed using the DCode Universal Mutation Detection System (BioRad, USA). The primers and DGGE method were described by McAuliffe et al. (16) with modifications (6). DNA from nasopharyngeal swabs was examined. DNA from the following strains was used as control: reference strain of $M$. bovis (ATCC 25523), type strains of M. bovigenitalium (ATCC 19852), M. bovoculi (ATCC 29104), and Acholeplasma laidlawii (ATCC 23206), and NCTC type strains of: $M$. canadense, M. canis, M. arginini, M. bovirhinis, M. dispar, M. alkalescens, M. mycoides subsp. mycoides SC, and $U$. diversum obtained from the Animal Plant and Health Agency, Weybridge, U.K.

\section{Results}

In total, $329(46.1 \%)$ cattle from all 73 herds showed the clinical signs possibly indicating mycoplasma infection. Apathy and appetite disturbances was observed in all examined herds, nasal discharge in $43(58.9 \%)$ herds, cough and dyspnea in $33(45.2 \%)$, swollen udder and joints in $8(11 \%)$, increased rectal temperature in $6(8.2 \%)$, high somatic cell counts and decreased level of milk production in 5 $(6.8 \%)$, abortions and infertility in $1(1.4 \%)$, and keratoconjunctivitis in $1(1.4 \%)$ out of all the herds tested.

Thirty-nine (5.5\%) samples were positive for M. bovis in the PCR. Forty PCR products (uvrC gene 
fragment), which were received directly from the swab or from culture when DNA concentration was low, were sequenced and submitted to NCBI GenBank (Table 2).

Table 2. Accession numbers of Polish $M$. bovis field strains and their territorial origin

\begin{tabular}{|c|c|c|}
\hline Province/region & Name of isolate & $\begin{array}{l}\text { NCBI GenBank } \\
\text { number }\end{array}$ \\
\hline \multirow{8}{*}{$\begin{array}{l}\text { Lublin/eastern } \\
\text { (herd no. 1) }\end{array}$} & 1_Mbovis_uvrC_PL & KP691391 \\
\hline & 2_Mbovis_uvrC_PL & KР691392 \\
\hline & 3_Mbovis_uvrC_PL & KР691393 \\
\hline & 4 Mbovis uvrC PL & KP691394 \\
\hline & 5_Mbovis_uvrC_PL & KP691395 \\
\hline & 6_Mbovis_uvrC_PL & KP691396 \\
\hline & 7_Mbovis_uvrC_PL & KР691397 \\
\hline & 8_Mbovis_uvrC_PL & KР691398 \\
\hline \multirow{6}{*}{$\begin{array}{l}\text { Lublin/eastern } \\
\text { (herd no. 2) }\end{array}$} & 9_Mbovis_uvrC_PL & KP691399 \\
\hline & 10_Mbovis_uvrC_ $\bar{C}$ PL & KР691400 \\
\hline & 11_Mbovis_uvrC_PL & KP691401 \\
\hline & 12_Mbovis_uvrC_PL & KР691402 \\
\hline & 13_Mbovis_uvrC_PL & KP691403 \\
\hline & 14_Mbovis_uvrC_PL & KP691404 \\
\hline \multirow{11}{*}{$\begin{array}{l}\text { Holy } \\
\text { Cross/eastern }\end{array}$} & 30_Mbovis_uvrC_PL & KU168357 \\
\hline & 31_Mbovis_uvrC_PL & KU168358 \\
\hline & 32_Mbovis_uvrC_PL & KU168359 \\
\hline & 33_Mbovis_uvrC_PL & KU168360 \\
\hline & 34_Mbovis_uvrC_PL & KU168361 \\
\hline & 35_Mbovis_uvrC_PL & KU168362 \\
\hline & 36_Mbovis_uvrC_PL & KU168363 \\
\hline & 37_Mbovis_uvrC_PL & KU168367 \\
\hline & 38 Mbovis uvrC PL & KU168364 \\
\hline & 39 Mbovis uvrC PL & KU168365 \\
\hline & 40 Mbovis uvrC PL & KU168366 \\
\hline Podlasie/eastern & 18 Mbovis uvrC PL & KU168351 \\
\hline \multirow{2}{*}{ Masovian/central } & 15_Mbovis_uvrC_PL & KU168342 \\
\hline & 16_Mbovis_uvrC_PL & KU168349 \\
\hline $\begin{array}{l}\text { Pomeranian/north } \\
\text { ern } \\
\text { (herd no. } 1)\end{array}$ & 29_Mbovis_uvrC_PL & KU168348 \\
\hline $\begin{array}{l}\text { Pomeranian/north } \\
\text { ern } \\
\text { (herd no. } 2 \text { ) }\end{array}$ & 17_Mbovis_uvrC_PL & KU168350 \\
\hline \multirow{2}{*}{$\begin{array}{l}\text { Greater Poland / } \\
\text { north-western }\end{array}$} & 19_Mbovis_uvrC_PL & KU168343 \\
\hline & 20 Mbovis uvrC PL & KU168344 \\
\hline \multirow{8}{*}{$\begin{array}{l}\text { Opole/south- } \\
\text { western }\end{array}$} & 21_Mbovis_uvrC_PL & KU168352 \\
\hline & 22_Mbovis_uvrC_PL & KU168353 \\
\hline & 23_Mbovis_uvrC_PL & KU168354 \\
\hline & 24_Mbovis_uvrC_PL & KU168345 \\
\hline & 25_Mbovis_uvrC_PL & KU168346 \\
\hline & 26 Mbovis uvrC PL & KU168355 \\
\hline & 27 Mbovis uvrC PL & KU168356 \\
\hline & 28 Mbovis uvrC PL & KU168347 \\
\hline
\end{tabular}

The nucleotide sequences were aligned with relevant sequences in GenBank and a dendrogram was plotted (Fig. 1). Six DNA isolates had point nucleotide mutations, such as transitions and transversions and the mutations resulted in amino acid substitutions (Table 3) as compared with the reference $M$. bovis PG45 (AF003959). The $u v r C$ nucleotide sequence of three isolates (KP691391, KP691395, and KP691396) showed $98.5 \%$ - 98.7\% identity with the reference M. bovis PG45 sequence (AF003959). The other three sequences (KP691393, KP691397, and KP691401) showed from $99.7 \%$ to $99.9 \%$ similarity, while the remaining 34 sequences $-100 \%$ similarity.
PCR/DGGE confirmed the presence of bacteria belonging to the Mollicutes class in 564 (79.1\%) DNA isolates from nasal swabs originating from 713 animals. The particular species identified were as follows: M. bovirhinis in 234/713 (32.8\%), M. dispar in 101/713 $(14.2 \%), M$. bovis in 66/713 (9.3\%), U. diversum in $55 / 713(7.7 \%)$, M. canis in $37 / 713(5.2 \%)$, M. arginini in $27 / 713(3.8 \%)$, M. canadense in $21 / 713(2.9 \%)$, M. bovoculi in $13 / 713(1.8 \%)$, and $M$. alkalescens in $10 / 713(1.4 \%)$ animals. M. bovis was the only species to be detected in $17 / 713(2.4 \%)$ animals, while in $49 / 713(6.9 \%)$ animals it co-occurred with another mycoplasma species and/or $U$. diversum (Fig. 2). M. bovirhinis, $M$. dispar, $U$. diversum, M. arginini, $M$. bovoculi, and M. alkalescens were detected as coinfections with $M$. bovis and in other kinds of coinfections. In DNA isolates from 498/713 (69.8\%) animals $U$. diversum and Mycoplasma spp. other than $M$. bovis were found. Interestingly, M. canis and $M$. canadense were not identified in co-infection with M. bovis. Moreover, M. bovigenitalium, M. mycoides subsp. mycoides SC or A. laidlawii were not detected, and no mycoplasmas were identified in 149/713 $(20.9 \%)$ DNA isolates.

Table 3. The type of mutations in the $u v r \mathrm{C}$ gene fragment and changes in amino acid sequences of Polish M. bovis field strains

\begin{tabular}{|c|c|c|c|}
\hline $\begin{array}{c}\text { NCBI } \\
\text { GenBank } \\
\text { accession } \\
\text { number }\end{array}$ & $\begin{array}{c}\text { Position } \\
\text { in nucleotide } \\
\text { sequence }\end{array}$ & $\begin{array}{c}\text { Change } \\
\text { in nucleotide }\end{array}$ & $\begin{array}{c}\text { Type } \\
\text { of mutation }\end{array}$ \\
\hline \multirow{15}{*}{$\begin{array}{l}\text { KP691391 } \\
\text { KP691395 } \\
\text { KP691396 }\end{array}$} & 99 & $\mathrm{C} \rightarrow \mathrm{T}$ & transition \\
\hline & 237 & $\mathrm{C} \rightarrow \mathrm{T}$ & transition \\
\hline & 550 & $\mathrm{C} \rightarrow \mathrm{T}$ & transition \\
\hline & 441 & $A \rightarrow G$ & transition \\
\hline & 525 & $A \rightarrow G$ & transition \\
\hline & 519 & $\mathrm{~A} \rightarrow \mathrm{T}$ & transversion \\
\hline & 555 & $\mathrm{C} \rightarrow \mathrm{T}$ & transition \\
\hline & 690 & $\mathrm{~T} \rightarrow \mathrm{C}$ & transition \\
\hline & 810 & $\mathrm{~T} \rightarrow \mathrm{C}$ & transition \\
\hline & 1001 & $\mathrm{C} \rightarrow \mathrm{T}$ & transition \\
\hline & 1050 & $\mathrm{C} \rightarrow \mathrm{T}$ & transition \\
\hline & 1056 & $\mathrm{C} \rightarrow \mathrm{T}$ & transition \\
\hline & 1092 & $\mathrm{~T} \rightarrow \mathrm{C}$ & transition \\
\hline & 1096 & $\mathrm{~A} \rightarrow \mathrm{T}$ & transversion \\
\hline & 1097 & $\mathrm{~A} \rightarrow \mathrm{C}$ & transversion \\
\hline \multirow{2}{*}{ KP691391 } & 864 & $\mathrm{G} \rightarrow \mathrm{C}$ & transversion \\
\hline & 1022 & $\mathrm{~T} \rightarrow \mathrm{G}$ & transversion \\
\hline \multirow{2}{*}{ KР691393 } & 917 & $\mathrm{G} \rightarrow \mathrm{C}$ & transversion \\
\hline & 920 & $\mathrm{~A} \rightarrow \mathrm{C}$ & transversion \\
\hline $\begin{array}{l}\text { KP691396 } \\
\text { KP691397 }\end{array}$ & 928 & $A \rightarrow C$ & transversion \\
\hline KP691401 & 1079 & $\mathrm{~T} \rightarrow \mathrm{G}$ & transversion \\
\hline \multicolumn{2}{|c|}{$\begin{array}{l}\text { NCBI GenBank } \\
\text { accession number }\end{array}$} & $\begin{array}{l}\text { Position in } \\
u v r \mathrm{C}\end{array}$ & $\begin{array}{c}\text { Change } \\
\text { in amino acid }\end{array}$ \\
\hline \multicolumn{2}{|c|}{ KP691391 } & 173 & $\mathrm{~L} \rightarrow \mathrm{F}$ \\
\hline \multicolumn{2}{|l|}{ KP691395 } & 334 & $\mathrm{~T} \rightarrow \mathrm{M}$ \\
\hline \multicolumn{2}{|l|}{ KP691396 } & 366 & $\mathrm{~N} \rightarrow \mathrm{S}$ \\
\hline \multirow{2}{*}{\multicolumn{2}{|c|}{ KP691391 }} & 228 & $\mathrm{E} \rightarrow \mathrm{D}$ \\
\hline & & 341 & $\mathrm{~V} \rightarrow \mathrm{G}$ \\
\hline \multirow{2}{*}{\multicolumn{2}{|c|}{ KР691393 }} & 307 & $\mathrm{~N} \rightarrow \mathrm{T}$ \\
\hline & & 306 & $\mathrm{~S} \rightarrow \mathrm{T}$ \\
\hline \multicolumn{2}{|l|}{ KP691396 } & 310 & $\mathrm{~T} \rightarrow \mathrm{P}$ \\
\hline \multicolumn{2}{|l|}{ KP691397 } & & $17 P$ \\
\hline \multicolumn{2}{|l|}{ KP691401 } & 360 & $\mathrm{M} \rightarrow \mathrm{R}$ \\
\hline
\end{tabular}


Twenty pure field strains of $M$. bovis were isolated, and the RAPD profiles of the isolates analysed with Hum1 contained few bands, so the RAPD profiles were obtained using Hum4 primer. All the isolated M. bovis strains showed RAPD patterns of high diversity (Fig. 3). It was demonstrated that the produced profiles formed two distinct groups (I and II) with only 3.8\% similarity.
Thirty percent of field strains were classified to group I and were divided into four subgroups (A-D). Seventy percent of field strains fell into group II and were further divided into two subgroups (F and $\mathrm{G})$ with $50 \%$ similarity. Nine strains which fell into subgroup $\mathrm{F}$ were homologous with five strains of subgroup $\mathrm{G}$.

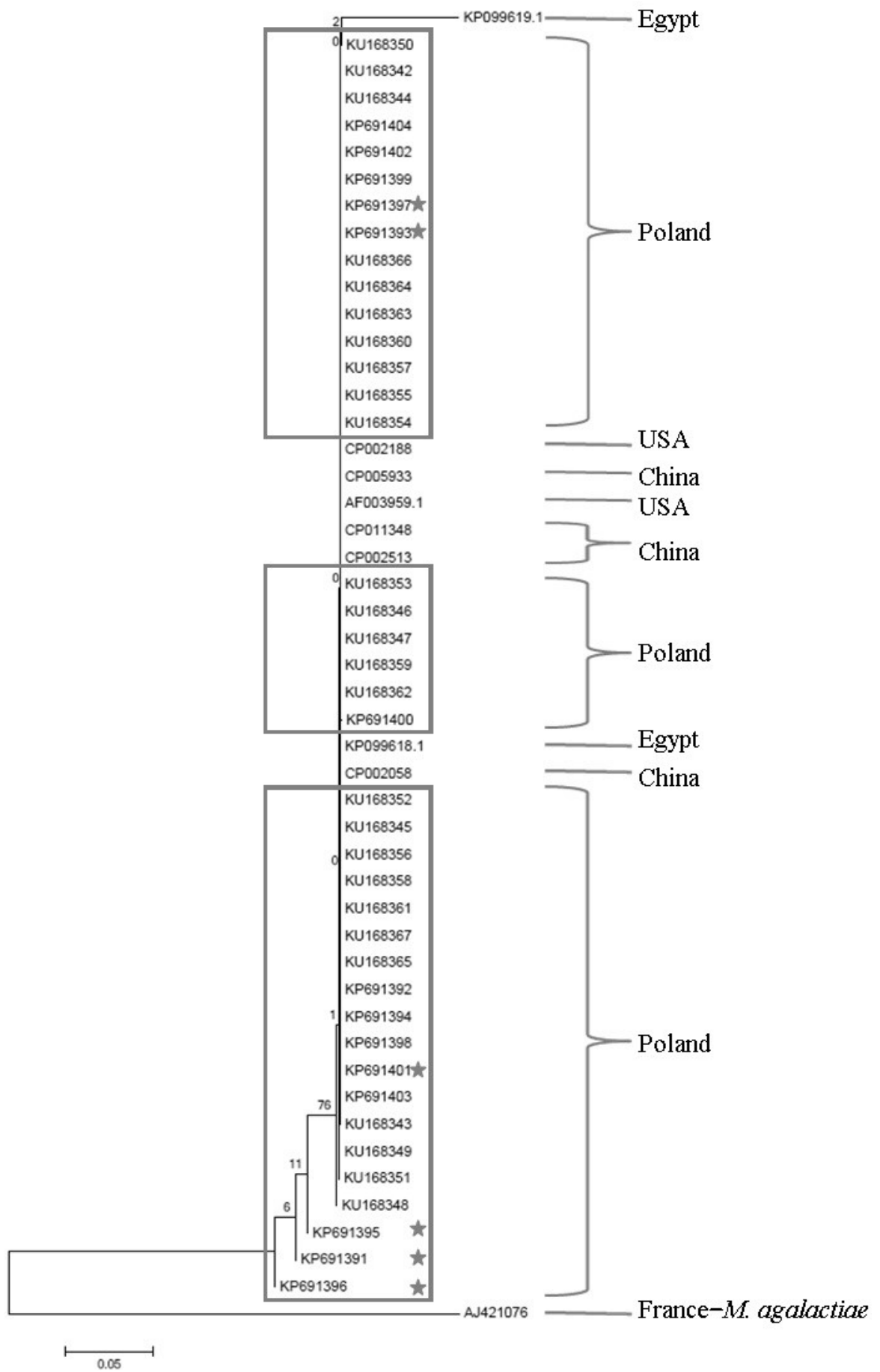

Fig. 1. Dendrogram of the phylogenetic relationship between the $u v r C$ gene fragments of Polish field strains, strains from different countries and related M. agalactiae strain. The asterisk marks the occurrence of mutation (1000-BOOTSTRAP) 


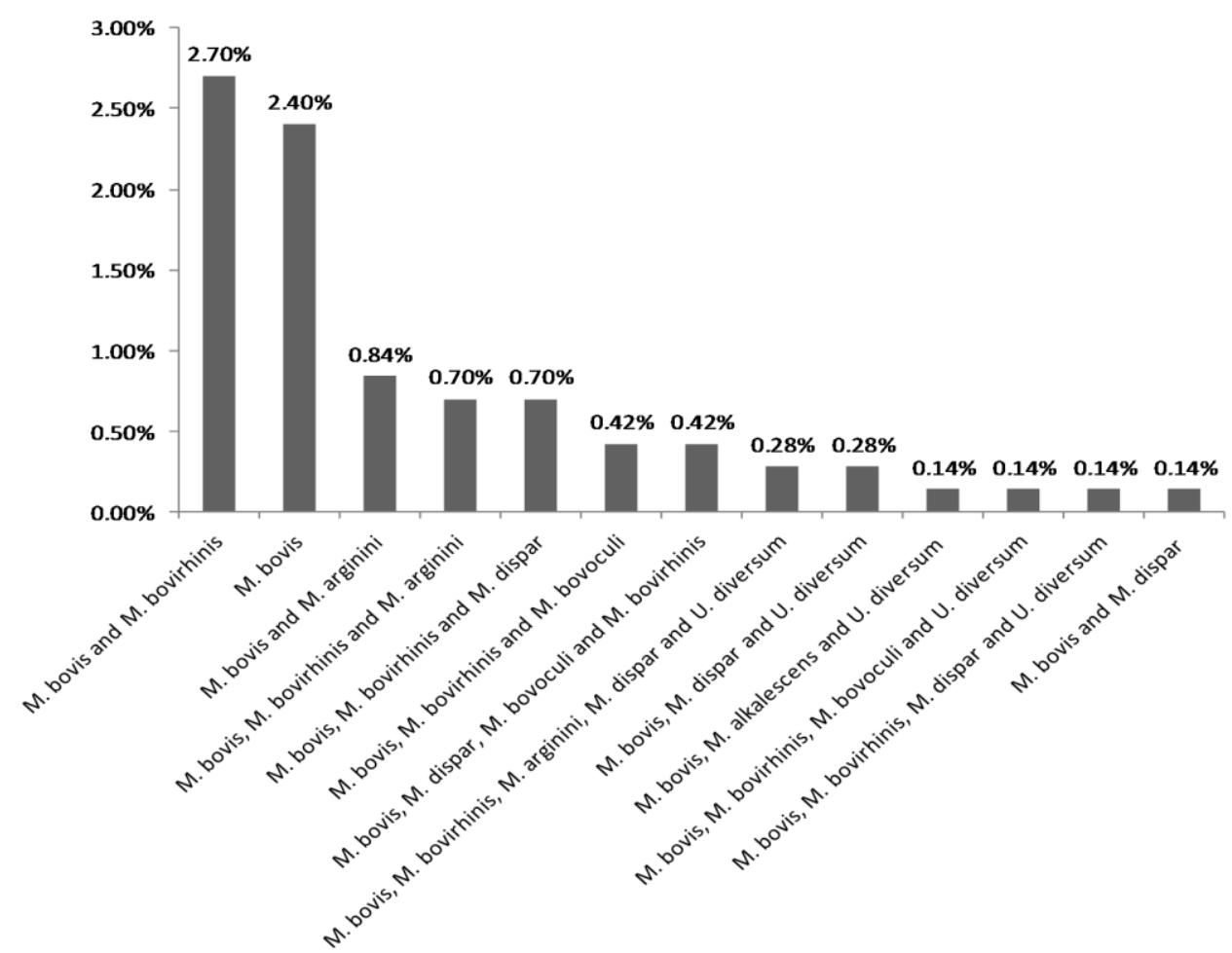

Fig. 2. M. bovis in co-infection with other Mycoplasma spp. and U. diversum



Fig. 3. Dendrogram of the phylogenetic relationship between Polish M. bovis isolates and the reference strain. Dendrogram was prepared on the basis of RAPD analysis. The asterisk marks the occurrence of mutation

\section{Discussion}

M. bovis infection represents a major disease burden for cattle producers worldwide, but other pathogens from the Mollicutes class should also be considered. Obtained results confirmed that the percentage of Mollicutes bacteria in nasal swabs from cattle affected with respiratory disease was 79.1. It should be noted that tested isolates contained DNA specific to one or more different Mycoplasma spp. and/or $U$. diversum. Co-infection in cattle herds is common in the course of respiratory diseases. Usually it is a co-infection with two or three Mycoplasma spp. $(12,13)$, while in our studies we detected even four or five different mycoplasmas in one animal. The prevalence of $M$. bovis, which is one of the most important bovine mycoplasmas, was $9.3 \%$. It should be noted that other species of bacteria occurred besides $M$. bovis. The highest prevalence was noted for $M$. bovirhinis and $M$. dispar, and lower for other Mycoplasma spp. and $U$. diversum. M. bovis plays a major role among the mycoplasmas in the infection of 
the respiratory tract in cattle, being isolated mainly from sick animals and rarely from healthy ones (30). Similarly to the results obtained in different countries $(5,12)$, in our study $M$. bovirhinis was the most often isolated mycoplasma. It is ubiquitous and known as a secondary pathogen in cases of calf pneumonia, and was most often detected among cattle with respiratory diseases (18). M. dispar and M. arginini were the next bacteria frequently encountered in our research. The first pathogen plays the primary role in infection, and the second one is regarded as an opportunist, being isolated rather rarely and mainly in co-infections with $M$. bovis $(5,9)$. $U$. diversum and $M$. canis are also significant in cattle respiratory diseases. M. canis is a canine mycoplasma, but it is also increasingly isolated from cattle pneumonia cases $(5,18)$. interestingly, $M$. bovoculi, which is responsible mainly for keratoconjunctivitis $(18,26)$, was found in nasal swabs in our study. M. canadense is not able to induce lung infection without other pathogens (25). In our study, M. canis and M. canadense were not found in co-infection with $M$. bovis, but in co-infection with other mycoplasmas $(12,20)$.

Following molecular typing with RAPD, the field strains isolated in Poland are known to fall into two groups: I and II. The mutations in the $u v r C$ gene were detected among the strains from RAPD group II and the strains originating from different regions of Poland, despite the fact that this group seemed to be more homogeneous. This finding is consistent with the data presented in Europe, where the lack of correlation between geographical origins of strains was also observed $(17,24)$. It is possible to speculate that the two distinct groups identified by RAPD in this study represent two clonal lines of origin. The isolates from group I were relatively more heterogeneous than isolates of group II, which may indicate slightly different rates of genetic drift between the two putative clonal lines. However, the highest number of mutations in the $u v r C$ gene was detected in strains from group II (subgroup F) and the mutations were 16 and 17 Single Nucleotide Polymorphisms (SNPs) for strains KP691391 and KP691396, respectively. It should be highlighted that this is the first report about the prevalence of mutations in the $u v r \mathrm{C}$ gene, which is considered conservative. In our study, we observed that some samples were negative in PCR testing while positive results were noted in PCR/DGGE. We can assume that it could be the result of mutations in the place of primer annealing in the $u v r \mathrm{C}$ gene sequence. Due to lack of PCR product, sequencing confirming the presence of mutations in these strains was impossible.

So far, M. bovis isolates have been characterised in some countries using genotyping tools such as RAPD, multilocus variable number tandem repeat (VNTR) analysis, and multilocus sequence typing (MLST) $(2,3,14,15,23,29)$ and it revealed that $M$. bovis strains are divided into two major clonal complexes. However, MLST results published by Dudek et al. (7) revealed that a Polish strain (not included in this study) did not cluster with any previously described clonal complexes. Therefore, in the future, other genotyping methods should be included in order to compare genetic diversity of Polish M. bovis strains with isolates from other countries. The nucleotide sequences derived from $u v r \mathrm{C}$ gene may provide additional information regarding genetic diversity of $M$. bovis field isolates. In our study, Polish M. bovis strains are found to be relatively homogenous and cluster closely with the type strain $M$. bovis PG45, which has a distinct geographical and temporal origin. When we compared the sequences of Polish strains with sequences of M. bovis from GenBank, all of them appeared to be closely related to the reference strain M. bovis PG45. It should be noted that the available sequences were obtained only from the USA, Egypt, and China, while there are no sequences ( $u v r C$ gene) of $M$. bovis strain from Europe in GenBank. Therefore, future analysis of the range of molecular characterisation of $M$. bovis in European countries, including Poland, is important.

In conclusion, different Mycoplasma spp. strains are present in cattle affected with respiratory diseases. $M$. bovis isolated from clinical cases plays an important role in aggravation of cattle pneumonia, but the role of other mycoplasmas cannot be ruled out. The demonstrated genomic heterogeneity among $M$. bovis strains confirms molecular and epidemiological differences and signifies an evolutionary dynamics of the $M$. bovis genome. The nature of the origin of $M$. bovis in Polish cattle is still not established, and it is only known that they are derivative of $M$. bovis PG45 strain. These findings underline the need for continuous surveillance not only in Poland but also in other European countries, to monitor the spread of $M$. bovis infection and mount effective control in order to minimise losses in the cattle industry.

Conflict of Interests Statement: The authors declare that there is no conflict of interests regarding the publication of this article.

Financial Disclosure Statement: The work was supported by the Polish National Science Centre research grant entitled: "The prevalence and molecular characteristics of Mycoplasma bovis infections in cattle in Poland" (2014-2016) conducted by the Department of Cattle and Sheep Diseases at the National Veterinary Research Institute in Poland.

Animal Rights Statement: According to the Local Ethical Committee on Animal Testing at the University of Life Sciences in Lublin (Poland) formal ethical approval is not required for this kind of study (22). 


\section{References}

1. Akwuobu C.A., Ayling R.D., Chah K.F., Oboegbulem S.I.: Studies into the prevalence of Mycoplasma species in small ruminants in Benue State, North-central Nigeria. Trop Anim Health Prod 2014, 46, 1087-1092, doi 10.1007/s11250-0140613-6.

2. Amram E., Freed M., Khateb N., Mikula I., Blum S., Spergser J., Sharir B., Ozeri R., Harrus S., Lysnyansky I.: Multiple locus variable number tandem repeat analysis of Mycoplasma bovis isolated from local and imported cattle. Vet J 2013, 197, 286290, doi: 10.1016/j.tvj1.2013.03.023.

3. Butler J.A., Pinnow C.C., Thomson J.U., Levisohn S., Rosenbush R.F.: Use of arbitrarily primed polymerase chain reaction to investigate Mycoplasma bovis outbreaks. Vet Microbiol 2001, 78, 175-181.

4. Byrne W., McCormack M., Hotzel H., Sachse K.: Variable surface protein expression profiles and PCR fingerprints of clinical isolates of Mycoplasma bovis from Irish cattle. In: Mycoplasmas of ruminants: pathogenicity, diagnostics, epidemiology and molecular genetics, vol. 5, Edited by Poveda B., Fernandez A., Johansson K.E., Frey J. European Commission, Brussels, Belgium 2000, pp. 14-17.

5. Chazel M., Tardy F., Le Grand D., Calavas D, Poumarat F.: Mycoplasmoses of ruminants in France: recent data from the national surveillance network. BMC Vet Res 2010, 6, 32.

6. Dudek K., Bednarek D., Ayling R.D., Kycko A., Szacawa E., Karpińska T.A.: An experimental vaccine composed of two adjuvants gives protection against Mycoplasma bovis in calves. Vaccine 2016, 34, 3051-3058.

7. Dudek K., Bednarek D., Szacawa E., Rosales R.S., Ayling R.D.: Flow cytometry follow-up analysis of peripheral blood leukocyte subpopulations in calves experimentally infected with field isolates of Mycoplasma bovis. Acta Vet Hung 2015, 63, 167178, doi: 10.1556/AVet.2015.014.

8. Ellis J.A.: The immunology of the bovine respiratory disease complex. Vet Clin North Am Food Anim Pract 2001, 17, 535549.

9. Hirose K., Kobayashi H., Ito N., Kawasaki Y., Zako M., Kotani K., Ogawa H., Sato H.: Isolation of mycoplasmas from nasal swabs of calves affected with respiratory diseases and antimicrobial susceptibility of their isolates. J Vet Med 2003, 347-351.

10. Hotzel H., Schneider B., Sachse K.: Investigation of Mycoplasma bovis field isolates using PCR fingerprint. In: Mycoplasma of ruminants: pathogenicity, diagnostics, epidemiology and molecular genetics, vol. 2, edited by Leori G., Santini F., Scanziani E., Frey J. European Commission, Brussels, Belgium 1998, pp. 17-19.

11. Jaccard P.: Nouvelles recherches sur la distribution florale. Bull Soc Vaudoise Sci Nat 1908, 44, 223-270.

12. Jozefová J., Ayling R.D., Zendulkowá D.: Report on investigations into the Mycoplasma species present in some clinically sick cattle in Czech Republic. Med Weter 2014, 70, 413-416.

13. Kokotovic B., Friis N.F., Ahrens P.: Mycoplasma alkalescens demonstrated in the bronchoalveolar lavage of cattle in Denmark. Acta Vet Scand 2007, 49, 2, doi:10.1186/1751-014749-2.

14. Lysnyansky I., Freed M., Rosales R.S., Mikula I., Khateb N., Gerchman I., van Straten M., Levisohn S.: An overview of
Mycoplasma bovis mastitis in Israel (2004-2014). Vet J 2016, 207, 180-183, doi: 10.1016/j.tvj1.2015.10.057.

15. Manso-Silván L., Dupuy V., Lysnyansky I., Ozdemir U., Thiaucourt F.: Phylogeny and molecular typing of Mycoplasma agalactiae and Mycoplasma bovis by multilocus sequencing. Vet Microbiol 2012, 161, 104-112, doi: 10.1016/j.vetmic.2012.07.015.

16. McAuliffe L., Ellis R.J., Lawes J.R., Ayling R.D., Nicholas R.A.J.: 16S rDNA PCR and denaturing gradient gel electrophoresis; a single generic test for detecting and differentiating Mycoplasma species. J Med Microbiol 2005, 54, 731-739.

17. McAuliffe L., Kokotovic B., Ayling R.D., Nicholas R.A.J.: Molecular epidemiological analysis of Mycoplasma bovis isolates from the United Kingdom shows two genetically distinct clusters. J Clin Microbiol 2004, 42, 4556-4565.

18. Nicholas R., Ayling R., McAuliffe L.: Mycoplasma Diseases of Ruminants. CABI, Wallingford, Oxfordshire, UK, 2008.

19. Nicholas R., Baker S.: Recovery of mycoplasmas from animals. In: Mycoplasma Protocols, edited by Miles R.J., Nicholas R.A.J. Humana Press, Totowa, USA, 1998, pp. 37-43.

20. Nicholas R.A.J., Ayling R.D., Stipkovits L.P.: An experimental vaccine for calf pneumonia caused by Mycoplasma bovis: clinical, cultural, serological and pathological findings. Vaccine 2002, 20, 3569-3575.

21. Nicholas R.A.J., Ayling R.D.: Mycoplasma bovis: disease, diagnosis and control. Res Vet Sci 2003, 74, 105-112.

22. Resolution No. 22/2006 of the National Ethics Committee for Experimentation of November 7, 2006, Poland.

23. Rosales R.S., Churchward C.P., Schnee C., Sachse K., Lysnyansky I., Catania S., Iob L., Ayling R., Nicholas R.A.J.: Global MLST analysis of Mycoplasma bovis isolates reveals two main population clusters J Clin Microbiol 2015, 53, 789-794.

24. Rosengarten R., Behrens A., Stetefeld A., Heller M., Ahrens M., Sachse K., Yogev D., Kirchhoff H.: Antigen heterogeneity among isolates of Mycoplasma bovis is generated by highfrequency variation of diverse membrane surface proteins. Infect Immun 1994, 62, 5066-5074.

25. Ross R.F.: Mycoplasma - animal pathogens. In: Rapid diagnosis of mycoplasmas, edited by Kahane I., Adoni A. Plenum Press, New York, 1993, pp. 69-109.

26. Schnee C., Heller M., Schubert E., Sachse K.: Point prevalence of infection with Mycoplasma bovoculi and Moraxella spp. in cattle at different stages of infectious bovine keratoconjunctivitis. Vet $\mathbf{J}$ 2015, 203, 92-96, doi: 10.1016/j.tvj1.2014.11.009.

27. Sneath P.H.A., Sokal R.R.: Numerical taxonomy. The principle and practice of numerical classification. WH Freeman and Co., San Francisco, 1973.

28. Subramaniam S., Bergonier D., Poumarat F., Capaul S., Schlatter Y., Nicolet J., Frey J.: Species identification of Mycoplasma bovis and Mycoplasma agalactiae based on the $u v r C$ genes by PCR. Mol Cell Probes 1998, 12, 161-169.

29. Sulyok K.M., Kreizinger Z., Fekete L., Jánosi S., Schweitzer N., Turcsányi I., Makrai L., Erdélyi K., Gyuranecz M.: Phylogeny of Mycoplasma bovis isolates from Hungary based on multi locus sequence typing and multiple-locus variable-number tandem repeat analysis. BMC Vet Res 2014, 7, 108, doi: 10.1186/17466148-10-108.

30. Thomas A., Ball H., Dizier I., Trolin A., Bell C., Mainil J., Linden A.: Isolation of Mycoplasma species from the lower respiratory tract of healthy cattle and cattle with respiratory disease in Belgium. Vet Rec 2002, 151, 472-476. 